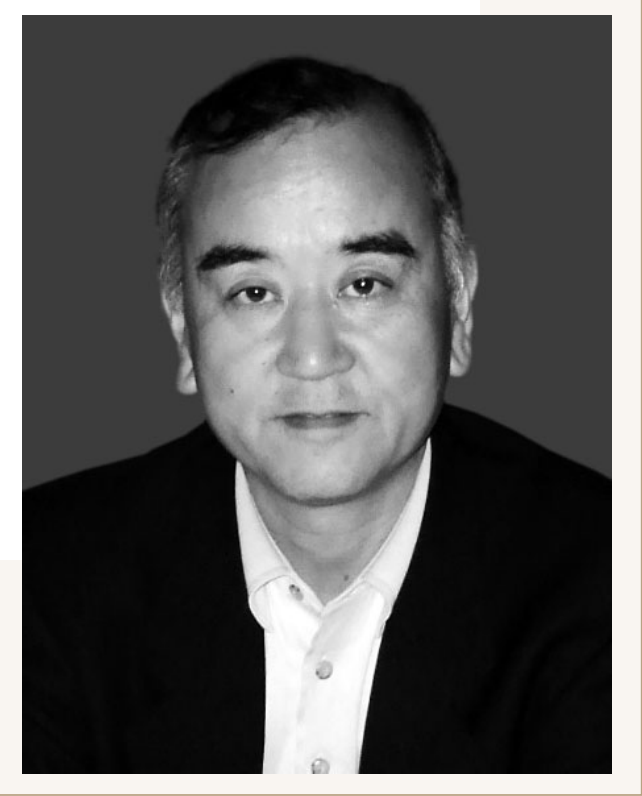

\title{
映像情報メディア技術の 将来は何処へ
}

\author{
中嶋正之
}

スウェーデン・ゴットランド大学 教授/東京工業大学世界文明センター・ディレクター

ちょっと古い話題で恐縮であるが，昨年韓国で麗水万博 が開催された。日本ではほとんど話題にならなかったが, 中嶋は本誌の昨年10月号に見聞記を掲載させて頂いた。そ の際，紙面の都合上, IT万博であるとの主題で紹介し, 各 パビリオンの催しの紹介が主となったが，個人的な感想と して，映像情報メディアに関係する以下の 2 点が気懸かり となっている.

(1) 開発途上国が躍進した万博

(2) CG, VR, 画像処理等の映像情報メディア技術が主役 として登場した万博

従来の万博は, アメリカ, 日本, ドイッ, フランス, な どOECDの加盟国が主体であった。しかし本万博は, 先進 国のパビリオンより開発途上国が注目を浴び，主役として 登場したとも言える。例えば，私自身オマーンという国は 名前はなんとなく聞いたことがあるが，どこにあるかさえ 知らなかったが, 本万博の最も人気のあるパビリオンで長 時間待ちとなった.

また従来の万博は, 巨大シアターにおける立体映像やパ ーフォーマンスの鑑賞が主であり，多くの方は，ただの聴 衆として受身で参加していたといえる. しかし麗水万博で は, 観客自らが参加する形態へ変化しつつあるとの感を強 くした. 画像処理, VRのみならず, そしてエージェント 技術，モーションキャプチャなどの最新のCG技術が積極 的に取り入れられていた。 まさに本学会の守備範囲である 映像情報メディア技術関連のイベントが主役として登場し た万博であると言える.

2点の共通の背景としては, PCの高機能化や携帯端末の
普及により，経済的には小規模な開発途上国においても気 軽にVR技術や画像処理技術を活用し, 映像メディア関連 コンテンツを制作し, 展示することが容易になったことが あると言える。 まさに将来は, 万博は映像情報メディア技 術関連のコンテンツのオンパレードとなるのではないかと も予感させられた.

さて結論であるが, 従来は, 先進技術の開発競争が主眼 となり, 先のみを見て最先端の映像メディア技術開発, 研 究や普及を考えていたのではないかとも思える.しかし多 くのアジア，アフリカの開発途上国が映像情報メディア技 術を活用する地球規模の映像メディア技術活用時代が迫っ ている，多くの経済分野と同様に，映像メディア技術にお いても国内市場は狭まっており, 今後どのように開発途上 国と向き合っていくかが，将来の映像情報メディア発展の キーポイントとなるのではないかとも言える.

話題は変わるが, 本学会の映像情報メディア関連の研究 会と電子情報通信学会の画像工学研究会が毎年交代で担当 している国際会議IWAIT (International Workshop on Advanced Image Technology) は, タイ,インドネシア, ベトナムと周り, 今年は早16回目を迎え，2013年1月7,8日 に名古屋で開催され，発表論文数208件，登録参加者数339 名（海外11力国からの51名を含む）となり，多大な成果を 得て終了した。谷本名古屋大学名誉教授 (元本学会会長) のもと, 中京地区ならびに関連研究会の委員の方々の多大 な努力の結果である．今後IWAITの役割はアジアの多く の国における映像情報メディア技術や研究の発展におい て, ますます重要になると予感させられた次第である. 